Biljana Ilić ${ }^{1}$

University of Megatrend, Belgrade,

Faculty of Management, Zajecar

Zoran Simonović

Institute of Agricultural Economics, Belgrade
SCIENTIFIC REVIEW ARTICLE

doi:10.5937/ekonomika1503085I

Received: August 6, 2015

Accepted: September 3, 2015

\title{
FACTORS OF SERBIAN SPA TOURSM AND ITS SUSTAINABILITY WITH REFERENCE TO GAMZIGRAD SPA
}

\begin{abstract}
Spas are whales rich in medicinal water, mud, air or other properties that help in the healing process. By analysing the factors of Serbian spa tourism, it can be determined their integrity and importance for the development of certain types of tourism, as well as the importance of these factors for the strengthening of the region in which the spas are located. Can Serbia rely on its own capabilities and resources? The answer to this question should be sought in the successful management of the country, its regions and the state of natural resources, in the establishment of proper national strategy for sustainable development. Given that Serbia has a considerable sources of renewable energy, among which occupies an important place and hydro energy, and that they are not utilized enough, both at the national and regional levels, the paper will try to give an overview of the factors of spa tourism with emphasis on Gamzigrad spa.
\end{abstract}

Key words: Spas, factors of spas tourism, strengthening the region, hydrogeothermal energy, Gamzigrad spa

JEL classification: Q00

\section{ГАМЗИГРАДСКА БАЫА- ФАКТОРИ БАЊСКОГ ТУРИЗМА И ЊИХОВ УТИЦАЈ НА РАЗВОЈ ЗАЈЕЧАРКОГ РЕГИОНА}

\begin{abstract}
Апстракт
Бање су лечилишта богата лековитом водом, блатом, ваздухом или другим својствима која помажу у проиесу оздрављења. Анализом фактора бањског туризма у Србији, може се утврдити њихова интегрисаност и значај за развој одређене врсте туризма, као и значај ових фактора за јачање региона у којима се бање налазе. Може ли се једна земља попут Србије ослонити на сопствене могућности и сопствене ресурсе? Одговоре на ова питања треба тражити у успешном руковођењу државом, ьеним регионима и државним природним ресурсима, у формирању правилне националне стратегије одрживог развоја. С обзиром да Србија обилује значајним изворима обновљивих видова енергије,
\end{abstract}

\footnotetext{
${ }^{1}$ biljana.ilic@fmz.edu.rs

2 zoki@medianis.net
} 
међу које важно место заузима и хидрогеотермална енергија, а да исти нису искоришћени довољно, како на државном, тако и на регионалном нивоу, у раду ће се покушати дати преглед фактора бањског туризма са освртом на Гамзиградску бању.

Кључне речи: Бање, фактори бањског туризма, јачање региона, хидоргеотермална енергија, Гамзиградска бана

\section{Introduction}

The development of tourism and its economic effects in the last few years, showed that it represents the future of the world economy. Therefore, new business concept is aimed in exploring new strategies in the development of tourism in relation to the preservation and improvement of the environment, meeting the increased needs and the realization of economic effects (Momirovic, 2008). Gamzigrad spa is one of the highlights registered spas in Serbia. It is located on the site $220 \mathrm{~km}$ southeast of Belgrade, near Zajecar. It is located at $160 \mathrm{~m}$ above sea level in the valley of the river Crni Timok, on the end of the main road Paracin - Zajecar. Gamzigrad spa has three rounded wholes, which consists of a unique tourist offer of Timok region: Institute for Rehabilitation, Company for Hotels and Tourism „Romulijana” and holiday centre workers “Elektrotimok Zajecar” (www. gamzigradskabanja.org.rs/). After considering the factors of Serbian spa tourism, with emphasis on Gamzigrad spa, the Paper gives an overview of the sustainability of Serbian tourism and hotel industry in the development of Serbian tourism.

\section{The effect of the presence of thermo-mineral and climatic factors in Serbian spas with regard to Gamzigrad spa}

Gamzigrad spa is rich in medical mineral water with temperature of the most abundant source of $42 *$ C. Table 1 presents the results of the assessment for 14 major spas Serbia (Matic, 2011).

Table 1. effect of the presence of thermo-mineral and climatic factors in Serbian spas

\begin{tabular}{|c|c|c|c|c|}
\hline & Classification of mineral water & $\begin{array}{l}\text { Mineral } \\
\text { water- } \\
\text { mark }\end{array}$ & $\begin{array}{l}\text { Climate } \\
\text { factors }\end{array}$ & $\begin{array}{l}\text { Rank natural } \\
\text { factors }\end{array}$ \\
\hline Niš Spa & $\begin{array}{l}\text { Hydrogen carbonate water, a } \\
\text { subclass of calcium, radon }\end{array}$ & 5 & 5 & 10 \\
\hline Soko Spa & $\begin{array}{l}\text { Hydrogen carbonate water, } \\
\text { subclass kalcijum.-magnesium- } \\
\text { radium radon }\end{array}$ & 5 & 5 & 10 \\
\hline Vrnjci Spa & $\begin{array}{l}\text { Hydrogen carbonate water, } \\
\text { subclass Sodium-Calcium- } \\
\text { Magnesium }\end{array}$ & 5 & 5 & 10 \\
\hline Atomska Spa & $\begin{array}{l}\text { Hydrogen carbonate water, } \\
\text { subclass Calcium-Magnesium }\end{array}$ & 5 & 5 & 10 \\
\hline
\end{tabular}




\begin{tabular}{|c|c|c|c|c|}
\hline Ribarska Spa & $\begin{array}{l}\text { Hydrocarbonate-sulfate water, } \\
\text { subclass The sodium }\end{array}$ & 5 & 5 & 10 \\
\hline Prolom Spa & $\begin{array}{l}\text { Hydrogen carbonate water, } \\
\text { subclass The sodium }\end{array}$ & 5 & 5 & 10 \\
\hline $\begin{array}{l}\text { Gamzigrad } \\
\text { Spa }\end{array}$ & $\begin{array}{l}\text { Hydrogen carbon. -chloride- } \\
\text { sulfate water, sodium subclass- } \\
\text { Calcium-magesium }\end{array}$ & 5 & 5 & 10 \\
\hline $\begin{array}{l}\text { Kovilja ča } \\
\text { Spa }\end{array}$ & $\begin{array}{l}\text { Hydrogen carbonate - a chloride } \\
\text { water, sodium-calcium subclass- } \\
\text { magnesium }\end{array}$ & 5 & 5 & 10 \\
\hline Kanjiža Spa & $\begin{array}{l}\text { Hydrogen carbonate water, } \\
\text { subclass The sodium }\end{array}$ & 5 & 4 & 9 \\
\hline $\begin{array}{l}\text { Junaković } \\
\text { Spa }\end{array}$ & $\begin{array}{l}\text { Hydrogen carbonate - chloride- } \\
\text { water, subclass The sodium }\end{array}$ & 5 & 4 & 9 \\
\hline Palić Spa & $\begin{array}{l}\text { Hydrogen carbonate - chloride- } \\
\text { water subclass The sodium }\end{array}$ & 5 & 4 & 9 \\
\hline $\begin{array}{l}\text { Slankamen } \\
\text { Spa }\end{array}$ & $\begin{array}{l}\text { Hydrogen carbonate water, } \\
\text { subclass Calcium-Magnesium }\end{array}$ & 5 & 4 & 9 \\
\hline Rusanda Spa & $\begin{array}{l}\text { Hydrochloric water, subclass The } \\
\text { sodium }\end{array}$ & 5 & 4 & 9 \\
\hline Vrdnik Spa & $\begin{array}{l}\text { Hydrogen carbonate water, } \\
\text { sodium-calcium subclass } \\
\text { magnesium }\end{array}$ & 5 & 5 & 10 \\
\hline
\end{tabular}

Source: Exploring the impact of development parameters of spa tourism, Matic, 2011.

Estimates are given for 1-5 thermo-mineral and climatic factors, while the total score for both factors ranging from 1-10. From the table it can be seen that the Gamzigrad spa has the highest marks by the composition of mineral water, according to climatic factors, as well as to the total natural factors. It is believed that the Romans used thermal mineral water of Gamzigrad spa, because they are far from them built the Imperial complex Felix Romuliana. Total number of indications for Gamzigrad spa is 9, and mineral water from its source has a positive effect in the treatment of diseases such as chronic occupational diseases, injuries and diseases of the peripheral nervous system, chronic non-communicable diseases of the skin, with posttraumatic conditions, gynecological diseases, injuries, and peripheral vascular disease, joint and soft tissue rheumatism, inflammatory and metabolic rheumatism, the overall recovery of the organism (Matic, Ilic, 2011).

\section{The accommodation in Serbian spas with regard to Gamzigrad spa, staff potential and wellness presence}

Based on the available data, it was found that Gamzigrad spa has most of the holiday accommodation, in addition to Sokobanja spa, Vrnjci spa and Niskabanja spa, whereas the total sum beds at the third position from the rear compared to other tested spas, or in 12th place (Matic, 2011). Vrnjačka Spa occupies first place ranking at the spa. 
It is accordingly a number of visits by tourists, significantly expanded accommodation facilities (http://smestajvrnjackabanja.com/). Most tourists when it comes to Serbia spas, choose hotel accommodation, because they get good service, quality meals, as well as numerous activities that they wanted to in accordance with their wishes. However, tourists are increasingly opting for private housing, which in recent years recorded rapid development in some spas in Serbia. Consequently, opened up more space for the night. Recommendation for Gamzigrad spa is definitely capacity expansion and introduction of new content to attract visitors.

Staff potential of Gamzigrad spa, compared with other major spas in Serbia is given in the text (Matic, 2011). Gamzigrad spa has a total of 142 employees (data from 2011), of which 73 medical staff and nonmedical 69. It is essential for the development of spa, especially medical tourism, investment in continuing education of employees, but not for medical purposes, but also in the way of hospitality and professional dealings with spa visitors. Ranking by the presence of wellness and wellbeing, Gamzigrad spa is on the $7^{\text {th }}$ place, after Vrnjci, Niš spa, Soko spa, Prolom spa, Atomska spa and Koviljaca spa. It can be concluded that the presence of such a special wellness center is not the case, but it is noted presence of certain segments in Gamzigrad wellness spa, which opens the possibility for further investment and the the entire program of spa products.

All 14 spas are the contents of cultural, historical, sports and recreational potential, the same ranking, but are listed facilities are insufficient, suggesting that there is scope for enlargement of that part of the offer. Acceptance and innovate inevitably points to the Gamzigrad spa. The sooner you accept the change, the greater the possibility of adapting the same (Matic, Ilic, 2011).

\section{Impact of Gamzigrad spa business on the development of the region}

Serbia represents a country with a very distinct regional differences, which are particularly pronounced among the most developed, the Belgrade region, and the least developed regions of Southern and Eastern Serbia

(http://www.pmf.ni.ac.rs/pmf/master/geografija/doc/2014/2014-02-05-rm.pdf).

However, much of the natural resources of Serbia is concentrated just in underdeveloped areas. This is a significant comparative advantage over developed regions and it provides the ability to underdeveloped areas to develop tourism, and efficient utilization of natural and climatic conditions, as well as improving existing facilities, ensuring efficient operations, faster economic growth, and thus regional development (Bogdanić , 2012). When it comes to the environment Gamzigrad spa, are evident knowledge since ancient times, with traces that mining near Bora has traces of knowledge of the healing waters Brestovacka Spa. Near Gamzigrad spa are monasteries Suvodol and Grliško monastery. In its surroundings, there is a mountain Rtanj, Zlot caves and a number of lakes, which certainly contributes to the attractiveness of the destination. Serbian spas in this region, are rich in extraordinary conditions for the preparation of athletes, which is very important for future development of Serbian tourism. It also has more facilities for various sports, a view of the clean air and mild climate, it is recommended to all who are looking for a good rest and a healthy environment. 


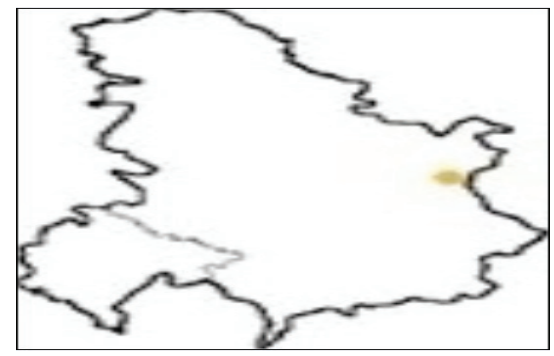

Figure 1. Gamzigrad Spa in Serbia

Source: http://www.gamzigradskabanja.org.rs/index.php/contact

Table 2 SWOT analisys for Zajecar district

\begin{tabular}{|c|c|}
\hline $\begin{array}{l}\quad S \quad \text { People } \\
\text { Production and Energy Resources } \\
\text { Tourism potential } \\
\text { Thermal springs } \\
\text { Traditional events } \\
\text { Administrative Centre } \\
\text { The position }\end{array}$ & $\begin{array}{l}\text { W Unemployment } \\
\text { Position of the city - from the distance of the } \\
\text { choir. } 10 \\
\text { Poor infrastructure of roads } \\
\text { Inadequately trained workforce } \\
\text { Obsolete machinery } \\
\text { Lack of development concept } \\
\text { Technological underdevelopment } \\
\text { Unresolved Property Issues }\end{array}$ \\
\hline $\begin{array}{l}\quad \mathrm{O} \text { The spa and health tourism } \\
\text { The position } \\
\text { Agriculture } \\
\text { Natural Resources } \\
\text { Cross-border cooperation } \\
\text { Decentralization and regionalization } \\
\text { Agribusiness }\end{array}$ & $\begin{array}{l}\mathrm{T} \text { The economic crisis } \\
\text { Unstable policy } \\
\text { Large population migrations from the } \\
\text { countryside } \\
\text { Great Migrations staff } \\
\text { Inadequate policies reg. development } \\
\text { The lack of a national strategy } \\
\text { Inconsistency strategy on attitudes. level } \\
\text { Inconsistency development policies }\end{array}$ \\
\hline
\end{tabular}

Source: Local strategy Plan

To the potential of this tourist destination could use and with minimal investment, it is necessary to examine and identify development opportunities, as well as the amount of investment in some directions in Gamzigrad spa.

Given that Gamzigrad spa falls under Zajecar district of Eastern Serbia (Fig. 1), Table 2 shows the general SWOT analysis of strengths, weaknesses, opportunities and threats for Zajecar district. It can be clearly seen that the spa and health tourism is an opportunity for development, while tourism potential and thermal springs are developmental force Zajecar districts. The use of geothermal resources of Gamzigrad have heating purposes Rehabilitation Institute to enable stimulate the energy increase of efficiency, and reduction of harmful gases released into the atmosphere by burning fossil fuels. Better heating of the building can attract consumers to come, because they would have better accommodation. Therefore, more consumers, would contribute to greater economic benefits. Introduction of wellness programs, as a special center will be 
good for Gamzigrad (hereinafter: Gamzigradska banja spa). Wellness is a term that first appeared in 1654 in the monograph by Sir A. Johnson as "wellness" in the dictionary Oxford Dictionary spelled "good health" (http://hr.wikipedia.org/wiki/Wellness). Based on the factors listed in the SWOT analysis, could be conceived program orientation to the strategy of development of spa tourism, which includes the following activities (Jovicic, 2008):

1. Develop a strategy with short- and long-term plans in cooperation with the Ministries Support the development of spa tourism;

2. Determine which market should turn;

3. Study and accept the principles of wellness and support private initiatives to Wellness in the creation of partnerships;

4. Implement education and training-Wellbeing Spa management development of branding, marketing and sales experience.

\section{Sustainability of tourism in Serbia based on the current state}

In addition to previously shown characteristics of the spas in Serbia, in order to get a clear picture of sustainability of tourism in Serbia, this Paper deals with cultural indicators. They are one of five groups of comparative indicators of sustainable tourism defined by the EU expert team. Besides the cultural indicators, the analysis involves economic, social and the environment indicators, as well as the level of how much tourists are satisfied. Cultural indicators show the level of the local population identity preservation being affected by tourists from regions with different cultural characteristics. This group of indicators includes the relation of accommodation capacities and number of local inhabitants and intensity of tourism (Bajic - Brkovic, 2010).

The relation of the accommodation capacities and number of local inhabitants is the indicator of cultural influence on the look of the touurist destination and requirements for necessary infrastructure which affects the community budget. The intensity of tourism shows the level of the culture saturation of the area. This indicator of sustainable tourism could be the most appropriate if, besides the number of stationed tourists, the number of excursionists, which is not registered, were taken into consideration (Stojanović, 2006). One of the reasons why the number of spa visitors is increasing is the fact that there are more and more inhabitants of old age. On the basis of the recent years statistical data, some of the spas in Serbia have been awarded the status of towns. Commercializing the functions with primary role of treatment, rehabilitation and recreation, the spas in Serbia have been demographicaly and economically developing, experiencing at the same time intensive urbanization. In the net-hierarchal structure of settlements in central Serbia, some of the spas represent the centers of the local significance of different functional rank, such as the municipality center (Vrnjacka spa, Niska spa and Sokobanja spa) and smaller places functionally complementary with the municipality center (Vranjska spa, Josanicka spa, Sijarinska spa, Koviljaca spa, etc. (Stamenkovic, Gataric, Martinovic, 2006).

Cultural indicators of tourism sustainability have been determined for spas as town settlements, however tourist resorts that do not have the status of tourist settlements should be taken into consideration as well. This invlolves the following spas: Vrujci spa, Bukovicka spa which is located on the urban teritory of the town of 
Arandjelovac, Gornjotrepcanska banja in the village of Gornja Trepca near the town of Cacak, and Bogutovacka spa near the village of Bogutovac in the valley of the river Ibar (Stamenkovic, Gataric, Martinovic, 2006). Although the number of old people, which is a negative factor of demographic transitions, is constantly increasing, the number of people who stay temporarily, as guests, or live permanently, as residents, in the spas is also going up. That is why we can consider it a positive demographic transition in spas which causes population and economic growth and development (Djurdjev, Kosic, Dragin, 2007).

Though the depopulation process has been registered in Serbia, some spas attract more and more guests. However, in the last few years, the trend of decreasing number of beds in Serbian spas has been registered due to property transformation and transfer to forms of private property. The accomodation capacities in the spas have been significantly reduced. This is the result of extremely unfavourable political and socio-economic relations (interest of the socio-political community, financial conditions, statistical survey of beds, Maćejka, 2003). Due to the fact that there is no intensive construction of tourist structures, the relation between accomodation capacities and number of local inhabitants in majority of spas in Serbia is favourable. The exceptions are the spas Gornja Trepca spa, Prolom spa, Sokobanja spa and Sijarinska spa in which there is a distinguishing difference between the accomodation capacities and number of guests. Naimely, there is a larger number of guests in these spas than the number of accomodation capacities.

In Prolom spa renting rooms in private houses has had a long tradition and almost all resided households do it. It provides them a significant source of income. In the structure of accomodation capaciites in Sokobanja spa, complementary accomodation capacities dominate, making some $90 \%$ of total number of capacities. Local tourist organizations operate with numbers much greater than official statistics for the whole reception, especially when it is about private accomodation. There are, for example, about 11.000 beds in Sokobanja spa, while in Vrnjacka spa, there are some 12.000 beds in private houses. In the functional structure of tourist resource basis in the spas, accomodation-catering industry structures distinguish. The look of the spa settlement changes although 'wild' construction had been present long before urban regulations were made (Vukoicic, 2008.).

If the analysis of the relation between the accomodation capacities and number of inhabitants included data from inofficial statistics, some spas in Serbia would have more distinguishing indicator of culture influence referring to the look of the resort itself and needs for necessary infrastructure. Analyses of the number of inhabitants in the last couple of years show that that number has not been significantly changed except in Bogutovacka spa, Gamzigradska banja spa and Sijarinska spa, in which it has been particularly reduced. The oscilations in the number of night stays are more prominent in larger spas in Serbia when it is about reduction of this indicator of tourism development.

Exquisite intensity of tourism, as indicator of cultural saturation, reflects negatively on the local environment. The problems arise about where to put the limit between tourist and general arrangement of the place necessary for the local population. The intensity of tourism in spas in Serbia points to very unfavourable situation since in the last years the obtained results have been in the red zone. The most unfavourable situation is in Prolom spa, Kursumlijska spa and Gornja Trepca spa, the state caused by a small number of 
local inhabitants, from one side, and relatively great number of night stays, on the other side. The cultural identity in the spas of Serbia has not been seriously damaged since it is mainly about differences in culture of guests coming from rural and urban areas. Urban expansion causes urban saturation, so that a significant number of structures in the spas is not in accordance with traditional architecture and, thus, endangers enviromental wholeness. Saturation means a disorder in the environment, ecological characteristics of certain area and anthropogenic values originated due to exceeding capacities. Regardless limits, each tourist area starts its development risking possible saturation. The lesser risk, the more anticipation of the future, more exact knowledge on limits of allowed development. Parallelly with the process of urbanisation, the number of inhabitants in a tourist destination grows, therefore, it is necessary to have good plans of tourism development and, in that way, evade undesirable consequences of saturation of the area in a local community (Sofield, 2003.).

When it is about planning in tourism, three principles should be taken into consideration. One of the principles in planning tourism on the local level are physical and visual or esthetic look of the location; it means that people should not build inappropriate structures and conduct unacceprtible activities. Stated measures involve the need to make an estimation of private capacities, regarding physical, social and economic conditions. The second principle refers to development of tourism based on possibilities for tourism defined by residental population. The third principle means that the development of tourism should be in accordance with plans of development of nontouristic activities (Richins, 2000). Regarding the stated principles in planning tourism on the local level, some negative consequences of saturation in the spas can be solved. In analyses of development of tourism in spas in future, what should be determined is the carrying capacity, so that it could be possible to determine the limits of allowed development. Comparative indicators or indicators of sustainable tourism in the EU provides a solid base for determining the sustainability level of development of tourism in definite tourist destinations. The results obtained by analysing cultural indicators of tourism sustainability of the Serbian spas partly satisfy the criteria of sustainable tourism prescribed by the EU experts. The relation between accomodation capacities and number of local inhabitants in the majority of spas can be defined as favourable (green zone) since it is not about intensive tourist construction. The exceptions are Gornja Trepca spa, Prolom spa, Sokobanja spa and Sijarinska spa.

However, the intensity of tourism or number of night stays, expressed in thousands, in relation to the number of inhabitants, expressed in hundreds, in spas of Serbia points to a very unfavourable situation since the obtained results in all investigated years were in the red zone. The most unfavourable situation is in Prolom spa, Kursumlijska spa and Gornja Trepca spa, the fact caused by a small number of local inhabitants, on one side, and relatively great number of night stays, on the other side. The next phase of development of spa tourism should involve the strategy based on definite instruments, measures and local initiative.

Due to spontaneous development of tourism in some spas in Serbia, it is necessary to encourage not only those who can achieve modern standards and quality in treatment, accomodation and other tourist activities but others as well. Those spas in Serbia, which will, through plan documents, involve their natural and cultural inheritance and which will adapt their offer to the needs of tourists and local population, have greater chances 
to develop. Quality and quantity of services in private sector depend on the level of education of the local population who is the main subject in offering this kind of tourist services.

That is why it is necessary to take measures such as stimulating various forms of private sector improvement, education, connecting private sector with commercial catering industry and tourist agencies. It is necessary to make the offer of the spa tourism in Serbia diversified by involving activities attracting various clientele. Infrastructure is imposed as a priority since 'wild' and excessive construction is not a good solution for including private sector in development of spas in Serbia. Cultural indicators of tourism sustainability are subjected to changes which depend on the situation on the tourist market. There are also some problems regarding the exploitation of capacities, average stay of tourists, as well as the season. New elements of tourist arrangement should be involved gradually and parallelly with renewing already existing facilities, taking into consideration existing urban regulation. The level of attractiveness of the area values can be improved by preserving identity of spas in Serbia. The way of building structures should be in accordance to the environment, so that the spas could develop in in-advancedefined direction and obtain definite character. To get a clear picture of the spa tourism in Serbia, we should say something more about the hospitality industry in Serbia.

\section{Hospitality Industry in Serbia and Perspectives of Tourism in Serbia}

On the basis of the estimation of the natural and anthropogenic resources which Serbia disposes of, including also human resources as the element of services offer, Serbia has real perspective chances to develop tourism, and hospitality industry, as a very important component of tourism. Certain conditions, particularly in economic-legal and managment-organizational domain are necessary to create a favourable environment for further investments in hospitality industry and whole tourism and its future development. Such investments should involve direct investments into hotels and other structures of tourist industry, as well as investment into getting knowledge and permanent education of the employees, then into research-developing projects, business connection of enterprises, organized enterprise marketing activities, organization and destination and other domains which will maximaze orientation to customers from Serbia and abroad and their requirements in the future.

On the tourist market, demands are changing and structurally adjusting to all significant economic, demographic, political and other tendencies. Realizers of travels, such as touroperators, airline and other transport companies, national and local tourist organizations and many others, adjust quickly and permanently to the changes of demands. Those adjustments have to involve current and developing policy in hospitality industry of each area tending to achieve success on tourist market. The strategy of the development of tourism in Serbia determined basic directions and range of development of hospitality industry up to 2015 (the Ministry of Trade, Tourism and Services, 2005/06). It is connected to possible scenario od development and previously defined tourist products with which Serbia can realize stated chances in tourism. The Strategy also defines the action plan for increasing competence of Serbian tourism, and in a significant measure involves necessary activities of the accomodation offer in hotels 
and elsewhere. Those activities include rehabilitation, renewing and modernization of existing capacities, new investment projects (greenfield projects), programmes of making the system of categorization and quality based on standards of accomodation and alike services (including introduction of new activities and structures, such as eco and ethno-houses, hostels, boutiques in hotels, etc.); programmes of additional offer which will complementarily follow accomodation capacities; improvement of cooperation and process of associating and business connection within the accomodation sector, with special emphasise on both mutual cooperation within the hospitality industry, in which the process of privatization is to be completed soon, and cooperation with public sector and its representatives (Cacic, 2015). During the years 2006 and 2007, strategic commitments were turned into elaboration of 11 business master plans for definite destinations or areas by using the finances of the National Investment Plan.

Those master plans, among all, thoroughly elaborate the development of hospitality industry in future and estimate the range of necessary investments of new or renewed capacities that those investments will make, and point to the type of hotels that should be built in accordance with demands of the market, that is, in accordance to the tourist products of the destination defined by the Strategy (town councils, business tourism, mountains and lakes, rural tourism, tourism of special interests, etc.). There are numerous spa and other destinations with good-quality resources and other conditions for further development. The same processes of development in the following years will take place in them.

Anyhow, regardless the fact whether master plans and other documents of development have been already worked out or they will be in future, the answers to at least two questions will be crucial for each investor and initiator of development in these spheres: firstly, what new or already existing, but modernized, to offer as new hotel and accompanying activity, and, secondly, how to organize activities in enterprises and destinations and conduct development. As far as the former concerned, it is necessary to estimate both domestic and international market and market demands, or possibilities by which additional value for consumers will be achieved and, in that way, make them loyal guests that will visit the destination again. It means that hotels and activities in them have to be precisely 'addressed' to certain segments of guests and efficiently adjusted to other tourist contents of the same quality in a certain destination. The contents based on the demands of the customers themselves and the economic racio should determine the capacity of a structure and its performances.

As far as the latter is concerned, it is essential to provide not only professional and efficient management, but also the whole personnel in an enterprise or destination, who are able to create appropriate environment for guets and offer them the feeling of additional value. This requires knowing relevant techniques and organization of menagement, that is, managing both total business and all modern business processes on the market (Ratkovic, 2007). We should count on such innovations in the following period. Foreign investors and other partners will bring innovations, and that is why it is extremely important for all managers and employees to be educated, so that they could readily react to the market requirements and provide competence of Serbian hospitality industry and tourism as a whole in the region and abroad. Developing activities are a part of the Action Plan for Improving Competition in the Strategy of Tourism Development in Serbia. The issue 'what to build' and 'how to organize activities and managing' is going to be present in several streams of development in future. Each of them will involve complex relations and procedures on which the realization of strategic aims of tourism in Serbia will significatly depend. Three such streams are quite certain and they will crucially orient further development. The first refers to entry of foreign 
companies and organizations on both hotel and whole tourist market of Serbia. They could be either interested investors, through greenfield projects or acquisition and common investment, or to offer some of contracted forms, such as franchizing, contract on menagment, by which they will ensure their own growth and development and enable more efficient business operations of our enterprises and destinations in the country and abroad. We are not to expect only great hotel corporations and the best-known world brends but also those who belong to the group of less-known but strong companies with developed international business and good market pozitions, as well as those with mainly standardized distinguishable structures of certain contents inteded to known target groups of guests. This is proved by experience of other tranzitional countries in Europe. In the mid 90s of the last century, it was observed that foreign investors and other partners tended to orient primarily to big cities as business, administrative and cultural centres and that they followed the streams of those segments, for example, business travellers, whom they primarily offered their services.

It is useful to remind that great hotel companies use largely the strategy of brand. That is how the strategy of international brand differs from the strategy of national brand. The former is used by the hotel companies characterized by high quality of services, and the point is that they do not significantly break into the market of a certain country, they cover the market through involving a larger number of countries instead of having a larger number of structures in a certain country. The strategy of a national brand is more oriented to the guests with medium and low incomes, and is used by the hotel companies which wish to attract attention of tourists in other countries. This is how it is broken onto the market of a certain country much deeper. Therefore, hotel companies in their growth and development use the strategy of brand in the following way: the strategy of a national brand ensures presence in a less number of countries with more units, while the strategy of international brand ensures presence in a larger number of countries with smaller number of units (Cacic, 1998.)

The second stream will involve completion of the process of privatization and restructuration in hospitality industry in Serbia (Barjaktarovic, 2008). This will make conditions for new investments and necessary changes in accordance with requirements on the market. Privatization is an additional opportunity for foreign partners to come, especially through the form of acquisition and merging, then through common investments, etc.

It is also a chence for the first strong national hotel chains which, independently from foreign partners, can create and develop hotel brands. The type and purpose of the hotel and its content should not be determined by intuition, faddiness and similar noneconomical initiations but by exclusively selective market criteria and economic factors.

The success in business of privatized enterprises in hospitality industry in the following period will be determined by general environment in the whole economic and tourist system in Serbia and adequate orientation and behaviour of new owners in relation to investment in development, social programmes and other significant areas of property transformations.

The third stream will determine the position of autonomous private sector which has been present in the hospitality industry in Serbia for a few years and whose further expansion can be expected in future. It is primarily about small and then medium family enterprises. They are flexible and their structures are suitable for completion of accomodation offer in all touristic products in Serbia defined by the Strategy.

Due to its characteristics, they can present very successfully the destination and specific values of the area, its architecture, national food, tradition, and through various original contents in hotels, significantly enrich accomodation and complete tourist offer. 
Hotels and other enterprises with accomodation capacities should be supported by public sector and large companies in the destination itself on all levels. Experience of numerous countries with developed tourism shows that, by measures of economic policy, family enterprises can efficially be supported and helped in development and business, and this is then one of the backings for the whole accomodation offer in the country. It is also realistic to expect that these enterprises can gradually appear and strenghten the processes of business connecting, primarily those related to bookings and other domains of selling, then promotion, exchange and professional improvement of the employees, and other activities.

It is possible for these enterprises to be connected into consortiums or chains and, thus, make a chance for themselves for more intensive and successful presence on both domestic and international market, as well as for competition with large companies in hospitality industry and tourism. Serbia is oriented to significantly faster and complete development of tourism in future years. Appropriate strategy has been adopted and thus, the tasks in this domain determined. It is quite real that conducting strategic orientations will require numerous activities in which it is important to evaluate correctly appropriate tendencies and relations among partcipants. It is especially important to provide adequate managing approach which means permanent adjustment to existing accomodation offer and new investments into hospitality industry and the whole tourism in Serbia in the following years.

\section{Conclusion}

The answer to the question, how to minimize the negative effects of tourism development in Serbia, while retaining the positive ones, could be "to look into the possibilities of sustainable tourism development". Today, sustainable development is one of the most acceptable, however, and most controversial approaches to management of tourist destinations. Sustainable tourism can be seen as the ultimate goal, which can not be fully achieved in practice (Ilic at al., 2012).

Although there is still no single definition of sustainable tourism, it can be said that this term implies a business that contributes to the protection of the environment, social and economic integrity and improving natural, created and cultural values on an ongoing basis "(http://www.lovetravel.rs / green-planet / sustainable-development-tourism).

To reach the level of development of European spas is necessary foe Serbia to highlight the specifics of individual spa resorts such as medical-health area, tourist facilities, etc., strengthen the Wellness program content as spa resorts, to educate all employees, starting from the top management, to medium and lower-level employees. The main tasks of the state are to support the development of the concept of publicprivate partnerships, then the cooperation and coordination with various stakeholders, such as government and parastatal bodies, associations, tourism and other businesses.

Spa centers should of course be a main part for marketing presentations, as well as the prominence of the most important tourist potential in the destination. Priority of Serbia should be a clear demarcation of those spa tourist destination that can successfully qualify for the foreign tourist market, from those who are predominantly oriented towards the domestic market. In other words, it is necessary to build the brand of Serbian spa tourism. 


\section{References}

Ilic B., Stojanovic D, .V. Jovanovic, D. Mihajlovic (2012) "Management in Sustainable Tourism Development of Serbian Spas“ Journal of Agricultural Science and Technology A, Volume 2, Number 12A, december 2012, 9-59

Bogdanic D. (2012) „Strategic basis for regional development of health tourism economy of Serbia" Faculty of management Zajecar

Jovicic D. (2008) „Condition and perspectives of spa tourism in Serbia“ p. 4-18.Bulletin of the Serbian Geographical Society - University of Belgrade - Faculty of Geography, Bulletin of the Serbian Geographical Society, Issue No. 88-. 4

Momirovic D. (2008) "Global tourism market trends: Challenge for Serbian tourism" Ekonomika, vol. 54, iss. 1-2, 75-89

Gmzigradska banja spa, taken from: http://www.gamzigradskabanja.org.rs/index.php/ contact (6.4.2015)

Local strategy of economic growth of Zajecar Districts, (2007), Document of Assembly town of Zajecar

Matić M. (2011) „Exploring the impact of development parameters of spa tourism “, Faculty of management Zajecar

Matić M., Ilić B. (2011) "Investigation of the influence of the developing parameters of the spa tourism", Proceedings of $1^{\text {st }}$ Symposium on Natural Resources Management with International participation, Faculty of management Zajecar, Bor, str. 321-328. ISBN 978-86-7747-431-7.

Sustainable tourism development, taken from: http://www.lovetravel.rs/zelenaplaneta/odrzivi-razvoj-turizma

Vrnjačka banja spa, taken from: http://smestajvrnjackabanja.com/ (4.4.2015)

Tourism as a factor of economic and regional development of the Republic of Serbia, taken from: http://www.pmf.ni.ac.rs/pmf/master/geografija/doc/2014/2014-0205-rm.pdf

Wellness, taken from: http://hr.wikipedia.org/wiki/Wellness (4.4.2015)

Bajic-Brkovic M. (2010), Sustainable development of spas in Serbia: Challenges and Perspective; The "Sustainable development of spas and resorts in Serbia" (special editions of books 64), Institute for Architecture and Urban Planning of Serbia, Belgrade

Stojanovic V. (2006), "Sustainable development of tourism and the environment", Faculty of Science, Department of Geography, Tourism and Hotel Management, Novi Sad

Stamenkovic S., Gataric Đ., Martinovic M. (2006), "Some issues of the status of spa resorts and spas in the Serbian settlements network", In Proceedings - Planning, development and protection of Spas of Serbia, Belgrade, Faculty of Geography, University of Belgrade and the Serbian Association of Spatial Planners

Đurđev B., Kosic K., Dragin A., (2007), "Demographic growth and development of spa resorts in Serbia", Bulletin de la Societe serbe de geographie, 87 (1),69-78.

Macejka M. (2003), "Climate and its importance in health spas in Serbia", Serbian Geographical Society, Belgrade 
Vukoicic D. (2008), "Spa tourism in function of Kursumlija municipality”, Serbian Geographical Society, Belgrade

Pavlovic S. (2011), "Tourism in the function of development of spa resort", Bulletin of the Serbian Geographical Society, 88 (4), 99-108

Sofield T, (2003), “Emprowerment for Sustainable Development”, Oxford: Pergamon Press

Richins H., (2000), Influences on Local Government tourism Decision-making: A Study of Authoritative Opinion, The Journal of Tourism Studies, 11 (2), 2-14.

Ministry of Trade, Tourism and Services (2005/06.), Tourism Development Strategy of Serbia, Horwath Consulting Zagreb and Faculty of Economics, Belgrade

Cacic K. (2008), Rising tendency in Serbian hospitality, Singidunum revija, Vol. 5, no. 1, 126-130.

Ratkovic R., (2007), "The organization and technique of hotel management", In Proceedings -"The hotel business," project "Education of employees in tourism Ministry of Trade, Tourism and Services and the Faculty of Tourism and Hospitality Management, University Singidunum,, University of Singidunum, Belgrade

Cacic K., (1998), "Business enterprises in tourism”, Faculty of Economics, Belgrade

Barjaktarovic D., (2008), "Business transformation of hotel companies in Serbia", Proceedings "Hotel business", Zlatibor 